\title{
Pro-oxidant potency of clothianidin in rainbow trout
}

\author{
Tarek Fakhereddin ${ }^{1}$ and Demet Doğan ${ }^{2}$ \\ ${ }^{1}$ University of Gaziantep Graduate School of Natural and Applied Sciences, Department of Biochemistry Science and \\ Technology, Şehitkamil, Turkey \\ ${ }^{2}$ University of Gaziantep Vocational School of Araban, Department of Veterinary Medicine, Araban, Turkey
}

[Received in January 2021; Similarity Check in January 2021; Accepted in May 2021]

Clothianidin is a systemic neonicotinoid insecticide interfering with the central nervous system by acting as a nicotinic acetylcholine receptor agonist. Although previous studies on fish report low toxicity, its proven toxic potential for aquatic invertebrates and lack of data on its effect on juvenile fish have prompted us to investigate its adverse effects in environmentally relevant concentrations of 3,15 and $30 \mu \mathrm{g} / \mathrm{L}$ for 7, 14 and 21 days on heart and spleen tissues of 10-monthold rainbow trout (Oncorhynchus mykiss). We detected a conspicuous increase in protein carbonyl and malondialdehyde (MDA) levels, which triggered antioxidant response of superoxide dismutase (SOD), catalase (CAT), and glutathione peroxidase (GPx), resulting in increased levels of glutathione (GSH). Clothianidin inhibited the activity of acetylcholinesterase (AChE) and lowered tissue protein levels. Heart tissue weight increased, while that of spleen decreased significantly. The effects were time- and concentration-dependent. What raises particular concern is the inhibition of $\mathrm{AChE}$ in the trout, even though clothianidin is claimed to be selective for insect receptors. Increased antioxidant activity in response to oxidative stress was clearly insufficient to keep MDA and protein carbonyl at normal levels, which evidences the pro-oxidant potency of the insecticide. All this calls for further investigation into potential adverse effects on biological pathways in different fish species.

KEY WORDS: AChE; CAT; fish; GPx; GSH; heart; MDA; neonicotinoids; Oncorhynchus mykiss; oxidative stress; SOD; spleen

Neonicotinoids are an important class of systemic insecticides, whose use for crop protection against piercing and sucking insects and animal health care started in the early 1990s. Their high solubility in water and slow breakdown in soil makes them readily absorbed by plants and has raised concern about leaching and transport in bodies of water (1), which is why they are listed as common contaminants of surface waters at concentrations in the $\mu \mathrm{g} / \mathrm{L}$ range (2).

Neonicotinoids act as agonists of nicotinic acetylcholine receptors (nAChRs), which play a crucial role in the synaptic transmission in the central nervous system of insects $(3,4)$. Due to their selectivity for insect receptors, they are believed to exert low toxicity in vertebrates, but growing recent evidence points to their ability to affect the vital functions of non-target species such as fish and mammals (5-7).

Clothianidin [(E)-1-(2-chloro-1,3-thiazol-5-ylmethyl)3-methyl2-nitroguanidine; CAS No. 210880-92-5] is the second commercialised neonicotinoid (the first was imidacloprid) and is one of the most polar and reactive members of the group. Its persistence and mobility in the ground and surface waters $(8,9)$ have resulted in its ban of

Corresponding author: Demet Doğan, University of Gaziantep Vocational School of Araban, Department of Veterinary Medicine, Araban, Turkey, E-mail: demetdogan@gantep.edu.tr use in flowering crops that appeal to honey bees (along with thiamethoxam and imidacloprid) by the European Commission (10) in 2013 and intensified investigations (11-13). In 2019, the United States Environmental Protection Agency (US EPA) cancelled its registration along with 11 other neonicotinoids, permitting the sale and distribution of leftover stocks until 20 May 2020 and regulating safe disposal beyond this deadline (14).

In the meantime, research of adverse effects of clothianidin moved to non-target aquatic invertebrate species $(15,16)$ and to the fish as one step up the food web, which resulted in a revision of its previously non-toxic status to slightly toxic (17). Investigation broadened to include various aspects of clothianidin toxicity, including neurotoxicity $(18,19)$ and behavioural impairment in rats (20) and oxidative stress and reproductive toxicity in rats, birds, and fish (21-23). However, as little is still known about its adverse effects in young fish, we decided to fill this gap by investigating the vulnerability of young rainbow trout (Oncorhynchus mykiss) to clothianidin toxicity by evaluating its effects through (i) anticholinesterase (AChE) activity, and (ii) oxidative stress in their heart and spleen tissues. 


\section{MATERIALS AND METHODS}

\section{Study species and water conditions}

The choice of trout was based on earlier evidence that this fish is highly sensitive to environmental changes (24) and can serve as a reliable bioindicator of acute and chronic toxicity (25). We used 48 10-month-old specimens (weighing $139.02 \pm 15.26 \mathrm{~g}$ and $19.23 \pm 1.68 \mathrm{~cm} \mathrm{long}$ ), purchased from a local breeder (Tunc Alabalık-Sanliurfa, Birecik, Turkey) and acclimatised to laboratory conditions for two weeks. They were held in $150 \mathrm{~L}$ water tanks with aerated tap water (under the 12/12 h dark/light cycle) and fed daily with commercial trout food (Optima troutSkretting, Muğla, Turkey) at a rate of $2 \%$ of their body weight throughout acclimatisation and exposure to clothianidin, except for the last $24 \mathrm{~h}$ before killing and immediate dissection.

The physico-chemical properties of water were as follows: temperature $16.96 \pm 0.32{ }^{\circ} \mathrm{C}, \mathrm{pH} 7.5 \pm 0.34$, dissolved oxygen $8.5 \pm 0.67 \mathrm{mg} / \mathrm{L}$, and conductivity $731.25 \pm 14.34 \mu \mathrm{S} / \mathrm{cm}$. These were maintained and checked twice daily with a multi-parameter water meter (84051 AZ Combo Water Meter-pH/COND./SALT/TDS/D.O, AZ Instrument Corp., Taichung City, Taiwan) before and after renewal of test solution (42 measurements in total).

The experimental protocols were authorized by the local Ethics Committee of Animal Experiments of Gaziantep University, under protocol No. 92 and decision No. 2019/13.

\section{Experimental design}

Following acclimatisation, the trout were divided into four groups of 12 . One served as control and other groups were exposed to three sublethal and environmentally relevant concentrations of analytical standard $(\geq 98 \%$ purity) clothianidin (PESTANAL ${ }^{\mathrm{TM}}$, MilliporeSigma Supelco, Munich, Germany) falling within reported ranges in water sources $(2,26-28)$, namely 3,15 , and $30 \mu \mathrm{g} / \mathrm{L}$. To obtain desired concentrations in the water tanks, clothianidin was dissolved in test water to prepare stock solutions and then diluted further as described elsewhere (29). These concentrations were checked and maintained daily through renewal bioassays.

Subacute toxicity was determined at 7-day sampling intervals (on days 7, 14, and 21).

\section{Sampling and analysis}

We determined oxidative stress through its adverse effects on lipids (lipid peroxidation) and proteins (protein carbonylation), activity of antioxidant enzymes superoxide dismutase (SOD), glutathione peroxidase (GPx), catalase (CAT), and the level of glutathione (GSH) as radical scavenger (30-33), while the selection of the heart and spleen tissues in which they were measured was based on their role in general fitness and adaptation to environmental conditions (heart) and the function of the immune system (spleen)

At the end of each exposure period, four randomly selected fish from each tank were anaesthetised with tricaine mesylate (MS-222, Sigma-Aldrich Chemie $\mathrm{GmbH}$, Taufkirchen, Germany) and euthanised by spinal cord section. Heart and spleen were carefully removed, washed with ice-cold physiological saline $(0.59 \% \mathrm{NaCl})$, weighted, and stored at $-80{ }^{\circ} \mathrm{C}$ until analysis. The weights of each heart and spleen were used to calculate heart and spleen somatic indexes (HSI and SSI) according to following formula:

Organosomatic index $=$ tissue weight/body weight x100 (34)

Frozen tissue samples were homogenised with $0.1 \mathrm{~mol} / \mathrm{L} \mathrm{pH} 7.4$ phosphate buffer saline (PBS) $(1: 5 \mathrm{w} / \mathrm{v}$, $0.2 \mathrm{~g}$ tissue $/ 1 \mathrm{~mL}$ buffer) and centrifuged at $9744 \mathrm{~g}$ and $4{ }^{\circ} \mathrm{C}$ for $30 \mathrm{~min}$ (Hettich Universal 320R, Sigma-Aldrich) to obtain post-mitochondrial supernatants.

MDA, GSH, and protein carbonyl were analysed with respective commercial enzyme-linked immunosorbent assay (ELISA) kits (Fish Malondialdehyde ELISA Kit, Cat. No E0017Fi; Fish Glutathione ELISA Kit, Cat. No EA0037Fi; Fish Protein Carbonyl ELISA Kit, Cat. No E0112Fi; Bioassay Technology Laboratory, Shanghai, China) using the quantitative sandwich method according to the manufacturer's instructions. Optical density was measured at $450 \mathrm{~nm}$ with a Thermo Scientific Multiscan GO microplate reader (Thermo Fisher Scientific Oy, Ratastie, Finland) and the quantity calculated from the standard curve. The standard curve range for MDA was $0.05-30 \mathrm{nmol} / \mathrm{mL}$, for protein carbonyl $1-400 \mathrm{ng} / \mathrm{mL}$, and the sensitivity for GSH was $0.25 \mathrm{nmol} / \mathrm{mL}$.

SOD, CAT, GPx, and AChE activities and protein levels in the supernatants were determined spectrophotometrically (Shimadzu UV Mini-1240, Shimadzu Corporation, Duisburg, Germany). SOD activity was analysed as described by McCord and Fridovich (35) through iodonitrotetrazolium chloride (INT, Sigma-Aldrich) reduction monitored at $505 \mathrm{~nm}$. The assay mixture was as follows: $0.01 \mathrm{~mol} / \mathrm{L}$ phosphate buffer $(\mathrm{pH} 7.0), 80 \mathrm{U} / \mathrm{L}$ xanthine oxidase (Sigma-Aldrich), $0.05 \mathrm{mmol} / \mathrm{L}$ xanthine (Sigma-Aldrich), $0.025 \mathrm{mmol} / \mathrm{L} \mathrm{INT}$, and $1 \mathrm{~mL}$ of tissue homogenate.

GPx activity was measured by monitoring dismutation of $t$-butylhydroperoxide (Sigma-Aldrich) at $340 \mathrm{~nm} \mathrm{(36).}$ The assay mixture contained $0.5 \mathrm{~mol} / \mathrm{L}$ Tris buffer $(\mathrm{pH} 8.0)$, $0.1 \mathrm{~mol} / \mathrm{L} \mathrm{GSH}, 10 \mathrm{U} / \mathrm{mL}$ of glutathione reductase (SigmaAldrich), $2 \mathrm{mmol} / \mathrm{L} \mathrm{NADPH}$ (Sigma-Aldrich), $7 \mathrm{mmol} / \mathrm{L}$ $t$-butylhydroperoxide, $660 \mu \mathrm{L}$ of distilled water, and $1 \mathrm{~mL}$ of tissue homogenate.

CAT activity was measured through the degradation rate of hydrogen peroxide at $230 \mathrm{~nm}$ in a reaction mixture of $1 \mathrm{~mol} / \mathrm{L}$ Tris buffer ( $\mathrm{pH} 8.0$ ), $10 \mathrm{mmol} / \mathrm{L} \mathrm{H}_{2} \mathrm{O}_{2}, 30 \mu \mathrm{L}$ distilled water, and $20 \mu \mathrm{L}$ tissue homogenate (36). 
AChE activity was measured according to Ellman et al. (37) by recording absorbance at $412 \mathrm{~nm}$ in a reaction mixture of $0.1 \mathrm{~mol} / \mathrm{L} \mathrm{pH}$ phosphate buffer $(\mathrm{pH} 8.0), 0.015 \mathrm{~mol} / \mathrm{L}$ acetylthiocholine iodide (Sigma Aldrich), $8.52 \mathrm{mmol} / \mathrm{L}$ ethopropazine (Sigma Aldrich), and $0.01 \mathrm{~mol} / \mathrm{L} \mathrm{5,5-dithiobis-}$ 2-nitrobenzoic acid (DTNB, Sigma-Aldrich).

Tissue protein levels were determined according to the method described by Lowry et al. (38) using bovine serum albumin (Sigma Aldrich) as standard.

\section{Statistical analysis}

All data were analysed using the SPSS v. 22 software (SPSS Inc., Chicago, IL, USA). Their distribution was checked for normality (Q-Q plot) and homogeneity of variance (Levene's test), respectively. Intergroup differences were assessed using one-way analysis of variance (ANOVA) followed by post-hoc least-significant difference test (LSD) $(\mathrm{p}<0.05)$. The strength of association between variables was tested with Pearson's correlation analysis. Results are given as means \pm standard error.

\section{RESULTS}

Changes in the analysed parameters following clothianidin exposure are presented as percentages of control.

\section{Organosomatic indices}

Heart and spleen somatic indices did not significantly differ from control on days 7 and 14 of exposure (Table 1). Significant changes were observed at $30 \mu \mathrm{g} / \mathrm{L}$ on day 21 . Heart somatic index increased $45 \%$ and spleen somatic index decreased $55 \%(\mathrm{p}<0.05)$.

\section{Protein levels}

In heart tissue, clothianidin exposure resulted in a $48 \%$ reduction $(\mathrm{p}<0.01)$ in tissue protein level on day 21 , while no significant changes were observed on days 7 and 14. A similar decreasing trend was observed for spleen tissue, with the highest reduction rate of $42 \%$ and $47 \%$ on days 14 and $21(\mathrm{p}<0.05)$ (Table 2).

\section{GSH}

GSH levels did not change significantly on days 7 and 14 , but increased $216 \%$ on day 21 day at $30 \mu \mathrm{g} / \mathrm{L}$ in heart tissue $(\mathrm{p}<0.01)$. In spleen tissue, the only significant change was the $90 \%$ increase at the $30 \mu \mathrm{g} / \mathrm{L}$ concentration on day $14(\mathrm{p}<0.01)$ (Table 2).

\section{Protein carbonyl}

Protein carbonyl levels showed an increase of $70 \%$, $69 \%, 184 \%$ in heart tissue on respective days 7,14 , and 21 of exposure to clothianidin at $30 \mu \mathrm{g} / \mathrm{L}(\mathrm{p}<0.05)$. In spleen tissue, the same concentration increased protein carbonyl levels $32 \%$ and $56 \%$ on days 14 and $21(\mathrm{p}<0.01)$ (Table 2).

\section{$M D A$}

In heart tissue, MDA levels increased $150 \%, 81 \%$, and $371 \%$ at the highest pesticide concentration on days 7,14 , and $21(\mathrm{p}<0.05)$. In spleen tissue, MDA levels significantly increased on days 14 and $21,54 \%$ and $63 \%$, respectively $(\mathrm{p}<0.01)$ (Table 2).

\section{Antioxidant enzyme activities}

Figure 1 shows changes in antioxidant enzyme activities in heart and spleen tissues. SOD sharply increased (198\%) only on day 21 in heart tissue, regardless of clothianidin concentration $(p<0.01)$. In spleen, it increased earlier at all tested concentrations, and the highest increase was $123 \%$ $(\mathrm{p}<0.01)$.

Similarly, heart CAT activity increased on day 21, reaching the maximum of $165 \%(r=0.795, p<0.01)$. Spleen

Table 1 Heart and spleen somatic indices in rainbow trout by weeks of exposure to clothianidin

\begin{tabular}{lccc}
\hline \multicolumn{3}{c}{ Somatic indices } \\
\hline \multicolumn{4}{c}{$\mathbf{1 4}$ days } \\
\hline days & $\mathbf{2 1}$ days \\
\hline $3 \mu \mathrm{g} / \mathrm{L}$ & $0.139 \pm 0.005^{\text {ax }}$ & $0.111 \pm 0.012^{\text {ax }}$ & $0.137 \pm 0.014^{\text {ax }}$ \\
\hline $15 \mu \mathrm{g} / \mathrm{L}$ & $0.155 \pm 0.030^{\text {ax }}$ & $0.149 \pm 0.021^{\text {ax }}$ & $0.158 \pm 0.024^{\text {ax }}$ \\
\hline $30 \mu \mathrm{g} / \mathrm{L}$ & $0.125 \pm 0.004^{\text {ax }}$ & $\mathbf{0 . 1 4 7} \pm \mathbf{0 . 0 1 9}$ & $\mathbf{0 . 1 7 8} \pm \mathbf{0 . 0 1 3} 3^{\text {by }}$ \\
\hline & & Spleen & \\
\hline Control & $0.204 \pm 0.053^{\text {ax }}$ & $0.225 \pm 0.048^{\text {ax }}$ & $0.206 \pm 0.010^{\text {ax }}$ \\
\hline $3 \mu \mathrm{g} / \mathrm{L}$ & $0.172 \pm 0.037^{\text {ax }}$ & $0.147 \pm 0.035^{\text {ax }}$ & $0.106 \pm 0.022^{\text {abx }}$ \\
\hline $15 \mu \mathrm{g} / \mathrm{L}$ & $0.287 \pm 0.065^{\text {ax }}$ & $0.154 \pm 0.030^{\text {ax }}$ & $0.113 \pm 0.012^{\text {abx }}$ \\
\hline $30 \mu \mathrm{g} / \mathrm{L}$ & $0.197 \pm 0.036^{\text {ax }}$ & $0.214 \pm 0.055^{\text {ax }}$ & $\mathbf{0 . 0 9 2} \pm \mathbf{0 . 0 0 9} 9^{\text {bx }}$ \\
\hline
\end{tabular}

Values are given as mean \pm standard error $(n=4)$. Superscript letters $a$ and $b$ indicate differences between exposure concentrations; superscript letters $\mathrm{x}$ and $\mathrm{y}$ indicate differences between durations $(\mathrm{p}<0.05)$ 
Table 2 Effects of environmental clothianidin exposure on protein ( $\mathrm{mg} / \mathrm{mL}), \mathrm{GSH}$ ( $\mathrm{nmol} / \mathrm{mg}$ protein), protein carbonyl (ng/mg protein), and MDA (nmol/mg protein) levels in heart and spleen tissues of rainbow trout

\begin{tabular}{|c|c|c|c|c|c|c|}
\hline & \multicolumn{3}{|c|}{ Heart } & \multicolumn{3}{|c|}{ Spleen } \\
\hline & \multicolumn{6}{|c|}{ Exposure duration (days) } \\
\hline & 7 & 14 & 21 & 7 & 14 & 21 \\
\hline \multicolumn{7}{|c|}{ Protein } \\
\hline Control & $5.35 \pm 0.27^{\text {ax }}$ & $5.63 \pm 0.39^{\mathrm{ax}}$ & $5.15 \pm 0.48^{\mathrm{ax}}$ & $6.85 \pm 0.78^{\mathrm{ax}}$ & $6.30 \pm 0.20^{\mathrm{ax}}$ & $7.15 \pm 0.85^{\text {ax }}$ \\
\hline $3 \mu \mathrm{g} / \mathrm{L}$ & $5.45 \pm 0.28^{\text {ax }}$ & $5.20 \pm 0.47^{\mathrm{ax}}$ & $4.75 \pm 0.30^{\text {ax }}$ & $6.93 \pm 0.60^{\text {ax }}$ & $6.20 \pm 0.70^{\mathrm{ax}}$ & $5.43 \pm 0.12^{\mathrm{abx}}$ \\
\hline $15 \mu \mathrm{g} / \mathrm{L}$ & $5.60 \pm 0.28^{\mathrm{ax}}$ & $5.15 \pm 0.39^{\text {axy }}$ & $4.50 \pm 0.27^{\text {ay }}$ & $7.28 \pm 0.92^{\mathrm{ax}}$ & $4.10 \pm 0.34^{\text {by }}$ & $4.55 \pm 0.31^{\text {by }}$ \\
\hline $30 \mu \mathrm{g} / \mathrm{L}$ & $5.38 \pm 0.36^{\text {ax }}$ & $4.63 \pm 0.52^{\mathrm{ax}}$ & $2.65 \pm 0.41^{\mathrm{by}^{*}}$ & $6.45 \pm 0.78^{\mathrm{ax}}$ & $3.67 \pm 0.57^{\text {by* }}$ & $3.78 \pm 0.36^{\text {by }}$ \\
\hline \multicolumn{7}{|c|}{ GSH } \\
\hline Control & $0.205 \pm 0.010^{\mathrm{ax}}$ & $0.244 \pm 0.017^{\mathrm{ax}}$ & $0.219 \pm 0.021^{\mathrm{ax}}$ & $0.257 \pm 0.031^{\mathrm{ax}}$ & $0.311 \pm 0.021^{\mathrm{ax}}$ & $0.313 \pm 0.035^{\mathrm{ax}}$ \\
\hline $3 \mu \mathrm{g} / \mathrm{L}$ & $0.210 \pm 0.012^{\mathrm{ax}}$ & $0.204 \pm 0.020^{\text {ax }}$ & $0.237 \pm 0.013^{\mathrm{ax}}$ & $0.160 \pm 0.024^{\mathrm{ax}}$ & $0.320 \pm 0.035^{\text {ay }}$ & $0.322 \pm 0.010^{\text {ay }}$ \\
\hline $15 \mu \mathrm{g} / \mathrm{L}$ & $0.217 \pm 0.010^{\text {ax }}$ & $0.195 \pm 0.015^{\mathrm{ax}}$ & $0.292 \pm 0.017^{\mathrm{ax}}$ & $0.173 \pm 0.020^{\mathrm{ax}}$ & $0.308 \pm 0.022^{\text {ay }}$ & $0.267 \pm 0.038^{\mathrm{axy}}$ \\
\hline $30 \mu \mathrm{g} / \mathrm{L}$ & $0.217 \pm 0.016^{\mathrm{ax}}$ & $0.310 \pm 0.041^{\mathrm{ax}}$ & $0.692 \pm 0.103^{\text {by* }}$ & $0.237 \pm 0.026^{\mathrm{ax}}$ & $0.591 \pm 0.075^{\mathrm{by}^{*}}$ & $0.387 \pm 0.030^{\mathrm{az}}$ \\
\hline \multicolumn{7}{|c|}{ Protein carbonyl } \\
\hline Control & $0.064 \pm 0.003^{\mathrm{ax}}$ & $0.077 \pm 0.005^{\mathrm{ax}}$ & $0.080 \pm 0.008^{\mathrm{ax}}$ & $0.205 \pm 0.021^{\mathrm{ax}}$ & $0.229 \pm 0.023^{\mathrm{ax}}$ & $0.207 \pm 0.018^{\mathrm{ax}}$ \\
\hline $3 \mu \mathrm{g} / \mathrm{L}$ & $0.077 \pm 0.005^{\mathrm{abx}}$ & $0.081 \pm 0.008^{\mathrm{ax}}$ & $0.068 \pm 0.008^{\mathrm{ax}}$ & $0.171 \pm 0.022^{\mathrm{ax}}$ & $0.192 \pm 0.009^{\mathrm{ax}}$ & $0.194 \pm 0.017^{\mathrm{ax}}$ \\
\hline $15 \mu \mathrm{g} / \mathrm{L}$ & $0.079 \pm 0.004^{\mathrm{abx}}$ & $0.060 \pm 0.005^{\mathrm{ax}}$ & $0.068 \pm 0.004^{\mathrm{ax}}$ & $0.174 \pm 0.016^{\mathrm{ax}}$ & $0.190 \pm 0.024^{\mathrm{ax}}$ & $0.268 \pm 0.015^{b x^{*}}$ \\
\hline $30 \mu \mathrm{g} / \mathrm{L}$ & $0.109 \pm 0.008^{b x}$ & $0.130 \pm 0.017^{\text {by* }}$ & $0.227 \pm 0.035^{\mathrm{bz}^{*}}$ & $0.205 \pm 0.024^{\mathrm{ax}}$ & $0.302 \pm 0.019^{\text {by* }}$ & $0.323 \pm 0.021^{\mathrm{cz}^{k}}$ \\
\hline \multicolumn{7}{|c|}{ MDA } \\
\hline Control & $0.100 \pm 0.004^{\mathrm{ax}}$ & $0.128 \pm 0.021^{\text {ax }}$ & $0.149 \pm 0.012^{\mathrm{ax}}$ & $0.428 \pm 0.051^{\mathrm{ax}}$ & $0.470 \pm 0.032^{\mathrm{ax}}$ & $0.376 \pm 0.044^{\mathrm{ax}}$ \\
\hline $3 \mu \mathrm{g} / \mathrm{L}$ & $0.153 \pm 0.009^{a b x}$ & $0.216 \pm 0.010^{\mathrm{abx}}$ & $0.194 \pm 0.011^{\mathrm{ax}}$ & $0.310 \pm 0.025^{\mathrm{ax}}$ & $0.353 \pm 0.038^{\mathrm{ax}}$ & $0.506 \pm 0.013^{\text {by }}$ \\
\hline $15 \mu \mathrm{g} / \mathrm{L}$ & $0.144 \pm 0.006^{\mathrm{ax}}$ & $0.178 \pm 0.006^{\mathrm{abx}}$ & $0.189 \pm 0.010^{\mathrm{ax}}$ & $0.374 \pm 0.017^{\mathrm{ax}}$ & $0.359 \pm 0.026^{\mathrm{ax}}$ & $0.540 \pm 0.034^{b y^{*}}$ \\
\hline $30 \mu \mathrm{g} / \mathrm{L}$ & $0.250 \pm 0.018^{b x^{*}}$ & $0.231 \pm 0.030^{b x}$ & $0.701 \pm 0.108^{\text {by* }}$ & $0.338 \pm 0.038^{\mathrm{ax}}$ & $0.722 \pm 0.095^{b y^{*}}$ & $0.612 \pm 0.044^{b y^{*}}$ \\
\hline
\end{tabular}

Values are given as mean \pm standard error $(\mathrm{n}=4)$. Superscript letters $\mathrm{a}, \mathrm{b}$, and $\mathrm{c}$ indicate differences between exposure concentrations; superscript letters $x, y$, and $z$ indicate differences between durations $(p<0.05) *$ Significance at $p<0.01$ level

tissue activity statistically rose at $30 \mu \mathrm{g} / \mathrm{L}$ on day 14 and at all tested concentrations on day 21 ( $\max .168 \%, \mathrm{p}<0.05)$.

GPx heart tissue activity also waited to significantly rise until day 21 at the highest clothianidin concentration (max. $194 \%, \mathrm{p}<0.01$ ). In spleen tissue, antioxidant response to the highest concentration came earlier to reach $118 \%$ and $44 \%$ increase on days 14 and 21 , respectively $(\mathrm{p}<0.01)$.

\section{AChE activity}

AChE activities started to significantly drop only at $30 \mu \mathrm{g} / \mathrm{L}$ on days 14 and 21 in heart tissue ( $25 \%$ and $44 \%$, respectively, $\mathrm{p}<0.01)$ and on day 21 in spleen $(27 \%$, $\mathrm{p}<0.05)$.

\section{Correlations}

Table 3 shows Pearson's correlation coefficients for all heart and spleen tissue parameters. Protein carbonyl and GSH levels and all antioxidant activities positively correlated with MDA in both tissues $(p<0.01)$. AChE activity negatively correlated with MDA levels $(p<0.01)$ only in heart tissue.

\section{DISCUSSION}

Our findings clearly evidence that environmentally relevant concentrations of clothianidin can induce oxidative stress, deplete protein levels, and inhibit AChE activity in time- and concentration-dependent manner.

The same is true for its effects on heart and spleen sizes. Heart somatic index increased, and spleen somatic index decreased. The observed heart enlargement reflects its susceptibility to cardiotoxic chemicals $(39,40)$ and may be explained by cardiac hypertrophy as an adaptive response to prolonged stress (41). Similar effects on spleen were reported for diazinon in African sharptooth catfish (Clarias gariepinus) (42), chlorpyrifos in Atlantic salmon (Salmo salar) (43), and lindane in Nile tilapia (Oreochromis niloticus) (44). This phenomenon may be owed to a release of red blood cells from the tissue into the circulation as a common stress response to enhance oxygen carrying capacity of the blood (45).

The observed decrease in protein levels in heart and spleen tissues of our trout was most likely a compensatory mechanism increasing proteolysis and/or energy requirements in response to a stressful condition, as reported elsewhere (46-48). 


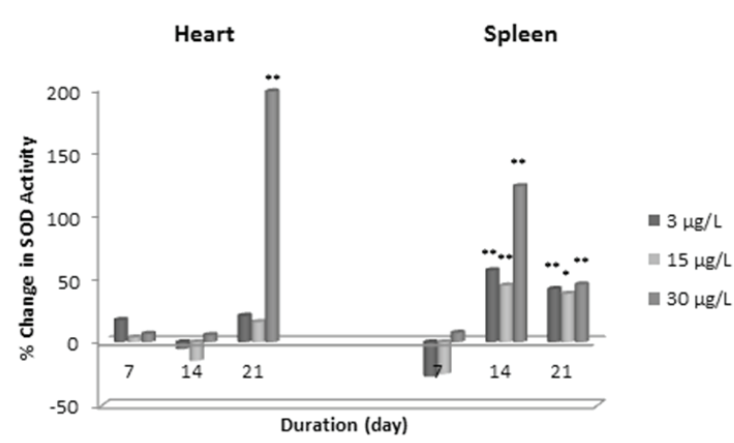

non-target organisms $(49,50)$. While some studies found no relevant changes in $\mathrm{AChE}$ activity, such as the one on imidacloprid effect in brain and muscle tissues of exposed streaked prochilod (Prochilodus lineatus) (51), others report significant changes with prolonged exposure $(52,53)$.

Earlier response to oxidative stress by spleen than heart tissue evidenced by increase in SOD activity points to its greater vulnerability. Concomitant rise in CAT and GPx activities and the observed changes in GSH levels evidence a disturbance in cellular $\mathrm{H}_{2} \mathrm{O}_{2}$. This increase was likely caused by increased transcription and/or translation due to lack of the posttranslational regulation (54) and reveals the pro-oxidant activity of clothianidin in juvenile rainbow trout. Similar findings were reported in other fish species after prolonged exposure to neonicotinoids (55-58).

Even though the activities of antioxidant enzymes and GSH levels rose, they could not mitigate oxidative stress, as MDA in both tissues remained high. Similar findings were also reported for other fish exposed to neonicotinoids $(52,53)$.

Increased protein carbonyl levels reinforced our findings of increased oxidative stress in both tissues caused by clothianidin. Protein carbonyls are reliable biomarkers of oxidative stress and usually follow changes in MDA (59, 60 ), and our findings support earlier reports on pesticide effects in fish (61-63).

\section{CONCLUSION}

Besides clearly showing that environmental concentrations of clothianidin can adversely affect young rainbow trout in a concentration- and time-dependent manner, this research provides an insight into its toxic mechanisms of action. The limitation inherent to the study design, however, is that it does not reflect real-life coexposure to other chemicals present in aquatic ecosystems, which may have additive or synergistic effects. Therefore, future studies should focus on an integrated risk neonicotinoid) anticholinesterase activity is minimal in

Figure 1 Change in mean SOD, CAT, and GPx enzyme activities in heart and spleen tissues of rainbow trout following clothianidin exposure with respect to control. * $\mathrm{p}<0.05 ; * * \mathrm{p}<0.01$

Our AChE findings seem to support other studies which warn about the fallacy that clothianidin (and generally Heart Spleen

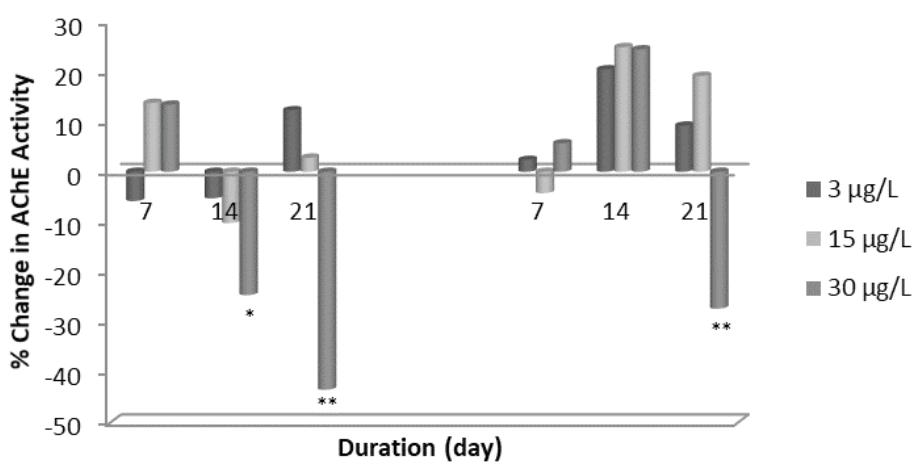

Figure 2 Change in mean $\mathrm{AChE}$ enzyme activity in heart and spleen tissues of rainbow trout following clothianidin exposure with respect to control. ${ }^{*} \mathrm{p}<0.05 ; * \mathrm{*}<0.01$ 
Table 3 Pearson correlation coefficients for heart and spleen tissue biomarkers in rainbow trout following clothianidin exposure

\begin{tabular}{|c|c|c|c|c|c|c|c|c|c|}
\hline & & Protein & $\begin{array}{l}\text { Protein } \\
\text { carbonyl }\end{array}$ & MDA & AChE & SOD & CAT & GPx & GSH \\
\hline \multirow{8}{*}{ Heart } & Protein & 1 & & & & & & & \\
\hline & Protein Carbonyl & $-0.788^{*}$ & 1 & & & & & & \\
\hline & MDA & $-0.760^{*}$ & $0.901^{*}$ & 1 & & & & & \\
\hline & AChE & $0.516^{*}$ & $-0.633^{*}$ & $-0.654^{*}$ & 1 & & & & \\
\hline & SOD & $-0.816^{*}$ & $0.874^{*}$ & $0.930^{*}$ & $-0.582^{*}$ & 1 & & & \\
\hline & CAT & $-0.671^{*}$ & $0.781^{*}$ & $0.809^{*}$ & $-0.437^{*}$ & $0.735^{*}$ & 1 & & \\
\hline & GPx & $-0.874^{*}$ & $0.849^{*}$ & $0.937^{*}$ & $-0.598^{*}$ & $0.951^{*}$ & $0.798^{*}$ & 1 & \\
\hline & GSH & $-0.855^{*}$ & $0.908^{*}$ & $0.942^{*}$ & $-0.624^{*}$ & $0.965^{*}$ & $0.792^{*}$ & $0.969^{*}$ & 1 \\
\hline \multirow{8}{*}{ Spleen } & Protein & 1 & & & & & & & \\
\hline & Protein Carbonyl & $-0.526^{*}$ & 1 & & & & & & \\
\hline & MDA & $-0.705^{*}$ & $0.650^{*}$ & 1 & & & & & \\
\hline & AChE & -0.254 & 0.225 & 0.218 & 1 & & & & \\
\hline & SOD & $-0.765^{*}$ & $0.505^{*}$ & $0.758^{*}$ & 0.265 & 1 & & & \\
\hline & CAT & $-0.736^{*}$ & $0.647^{*}$ & $0.749^{*}$ & 0.141 & $0.725^{*}$ & 1 & & \\
\hline & GPx & $-0.789^{*}$ & $0.589^{*}$ & $0.818^{*}$ & 0.239 & $0.924^{*}$ & $0.723^{*}$ & 1 & \\
\hline & GSH & $-0.664^{*}$ & $0.576^{*}$ & $0.832^{*}$ & 0.165 & $0.853^{*}$ & $0.597^{*}$ & $0.927^{*}$ & 1 \\
\hline
\end{tabular}

${ }^{*} \mathrm{p}<0.01$ (Pearson correlation analysis, 2-tailed)

assessment of combined environmental exposure through combined treatment or a mesocosm experiment. Additional studies with fish at different life stages, including larval and embryonic, could shed more light of the mechanisms of action.

\section{Conflicts of interest}

None to declare.

\section{Acknowledgement}

This study was financed by the Gaziantep University Scientific Research Projects Coordination Unit (AMYO. YLT.19.01). Heart and spleen were provided separately through the Scientific and Technological Research Council of Turkey (TUBITAK) project No. 118Z593.

\section{REFERENCES}

1. Frederickson D, Wohlman M, Stoddard D, Regimbal G, Scholer J, Zachmann J, Ortiz-Ribbing L, Mann R. Review of neonicotinoid use, registration, and insect pollinator impacts in Minnesota, 2016 [displayed 4 February 2020]. Available at https://www.mda.state.mn.us/sites/default/files/inline-files/ neonicreviewrpt2016.pdf

2. Morrissey CA, Mineau P, Devries JH, Sanchez-Bayo F, Liess M, Cavallaro MC, Liber K. Neonicotinoid contamination of global surface waters and associated risk to aquatic invertebrates: a review. Environ Int 2015;74:291-303. doi: 10.1016/j.envint.2014.10.024

3. Casida JE, Durkin KA. Neuroactive insecticides: targets, selectivity, resistance, and secondary effects. Annu Rey Entomol 2013;58:99-117. doi: 10.1146/annurevento-120811-153645
4. Wood T, Goulson D. The environmental risks of neonicotinoid pesticides: a review of the evidence post 2013. Environ Sci Pollut Res 2017;24:17285-325. doi: 10.1007/s11356-0179240-x

5. Kapoor U, Srivastava MK, Trivedi P, Garg V, Srivastava LP. Disposition and acute toxicity of imidacloprid in female rats after single exposure. Food Chem Toxicol 2014;68:190-5. doi: 10.1016/j.fct.2014.03.019

6. Lonare M, Kumar M, Raut S, Badgujar P, Doltade S, Telang A. Evaluation of imidacloprid-induced neurotoxicity in male rats: a protective effect of curcumin. Neurochem Int 2014;78:122-9. doi: 10.1016/j.neuint.2014.09.004

7. Crosby EB, Bailey JM, Oliveri AN, Levin ED. Neurobehavioral impairments caused by developmental imidacloprid exposure in zebrafish. Neurotoxicol Teratol 2015;49:81-90. doi: 10.1016/j.ntt.2015.04.006

8. Zhang C, Tian D, Yi X, Zhang T, Ruan J, Wu R, Chen C, Huang $\mathrm{M}$, Ying G. Occurrence, distribution and seasonal variation of five neonicotinoid insecticides in surface water and sediment of the Pearl Rivers, South China. Chemosphere 2019;217:43746. doi: 10.1016/j.chemosphere.2018.11.024

9. Schepker TJ, Webb EB, Tillitt D, LaGrange T. Neonicotinoid insecticide concentrations in agricultural wetlands and associations with aquatic invertebrate communities. Agr Ecosys Environ 2020;287:106678. doi: 10.1016/j. agee.2019.106678

10. Commission Implementing Regulation (EU) No 485/2013 of 24 May 2013 amending Implementing Regulation (EU) No 540/2011, as regards the conditions of approval of the active substances clothianidin, thiamethoxam and imidacloprid, and prohibiting the use and sale of seeds treated with plant protection products containing those active substances [displayed 15 May 2021]. Available at: https://eur-lex.europa. eu/eli/reg_impl/2013/485/oj

11. Schmuck R, Lewis G. Review of field and monitoring studies investigating the role of nitro-substituted neonicotinoid 
insecticides in the reported losses of honey bee colonies (Apis mellifera). Ecotoxicology 2016;25:1617-29. doi: 10.1007/ s10646-016-1734-7

12. Tsvetkov N, Samson-Robert O, Sood K, Patel H, Malena D, Gajiwala P, Maciukiewicz P, Fournier V, Zayed A. Chronic exposure to neonicotinoids reduces honey bee health near corn crops. Science 2017;356:1395-7. doi: 10.1126/science. aam7470

13. Auteri D, Arena M, Barmaz S, Ippolito A, Linguadoca A, molnar T, Sharp R, Szentes C, Vagenende B, Verani A. Neonicotinoids and bees: The case of the European regulatory risk assessment. Sci Total Environ 2017;579:966-71. doi 10.1016/j.scitotenv.2016.10.158

14. Federal Register. Product Cancellation Order for Certain Pesticide Registrations 2019, Vol. 84, No. 97 [displayed 4 February 2020]. Available at https://www.govinfo.gov/content/ pkg/FR-2019-05-20/pdf/FR-2019-05-20.pdf

15. Anderson JC, Dubetz C, Palace VP. Neonicotinoids in the Canadian aquatic environment: A literature review on current use products with a focus on fate, exposure, and biological effects. Sci Total Environ 2015;505:409-22. doi: 10.1016/j. scitotenv.2014.09.090

16. Pisa LW, Amaral-Rogers V, Belzunces LP, Bonmatin JM, Downs CA, Goulson D, Kreutzweiser DP, Krupke C, Liess M, McField M, Morrissey CA, Noome DA, Settele J, SimonDelso N, Stark JD, Van der Sluijs JP, Van Dyck H, Wiemers M. Effects of neonicotinoids and fipronil on non-target invertebrates. Environ Sci Pollut Res Int 2015;22:68-102. doi: 10.1007/s11356-014-3471-x

17. Health Canada, Pest Management Regulatory Agency. Registration Decision RD2013-14, Clutch 50 WDG, Arena 50 WDG and Clothianidin Insecticides [displayed 12 March 2021]. Available at https://cela.ca/wp-content/uploads/2019/07/ Notice_of_Objection_Letter_with_Appendices

18. Li P, Ann J, Akk G. Activation and modulation of human $\alpha 4 \beta 2$ nicotinic acetylcholine receptors by the neonicotinoids clothianidin and imidacloprid. J Neurosci Res 2011;89:1295301. doi: $10.1002 /$ jnr.22644

19. Faro LRF, Oliveira IM, Durán R, Alfonso M. In vivo neurochemical characterization of clothianidin induced striatal dopamine release. Toxicolog 2012;302:197-202. doi: 10.1016/j.tox.2012.07.017

20. Tanaka T. Effects of maternal clothianidin exposure on behavioral development in F1 generation mice. Toxicol Ind Health 2012;28:697-707. doi: 10.1177/0748233711422726

21. Tokumoto J, Danjo M, Kobayashi Y, Kinoshita K, Omotehara T, Tatsumi A, Hashiguchi M, Sekijima T, Kamisoyama H, Yokoyama T, Kitagawa H, Hoshi N. Effects of exposure to clothianidin on the reproductive system of male quails. J Vet Med Sci 2013;75:755-60. doi: 10.1292/jvms.12-0544

22. Hirano T, Yanai S, Omotehara T, Hashimoto R, Umemura Y, Kubota N, Minami K, Nagahara D, Matsuo E, Aihara Y, Shinohara R, Furuyashiki T, Mantani Y, Yokoyama T, Kitagawa $\mathrm{H}$, Hoshi N. The combined effect of clothianidin and environmental stress on the behavioral and reproductive function in male mice. J Vet Med Sci 2015;77:1207-15. doi: 10.1292/jvms. 15-0188

23. Marlatt VL, Leung TYG, Calbick S, Metcalfe C, Kennedy C. Sub-lethal effects of a neonicotinoid, clothianidin, on wild early life stage sockeye salmon (Oncorhynchus nerka). Aquat Toxicol 2019;217:105335. doi: 10.1016/j.aquatox.2019.105335
24. Rasmussen JB, Rowan DJ, Lean DRS, Carey JH. Food chain structure in Ontario Lakes determines PCB Levels in lake trout (Salvelinus namaycush) and other pelagic fish. Can J Fish Aquat Sci 1990;47:2030-8. doi: 10.1139/f90-227

25. Organisation for Economic Co-operation and Development (OECD). Guideline for the Testing of Chemicals: Fish, Acute Toxicity Test. Part 203, 1992. Adopted by the Council on July 17, 1995 [displayed 12 April 2021]. Available at https://www. oecd.org/chemicalsafety/risk-assessment/1948241.pdf

26. Samson-Robert O, Labrie G, Chagnon M, Fournier V. Neonicotinoid-contaminated puddles of water represent a risk of intoxication for honey bees. PLoS One 2014;9(12):e108443. doi: 10.1371/journal.pone. 0108443

27. Inyang IR, Ollor AO, Izah SC. Effect of diazinon on organosomatic indices and behavioural responses of Clarias gariepinus (a common Niger Delta wetland fish). Greener J Biol Sci 2017;7:15-9. doi: 10.15580/GJBS.2017.2.020917021

28. Huseth AS, Groves RL. Environmental fate of soil applied neonicotinoid insecticides in an irrigated potato agroecosystem. PLoS One 2014;9(5):e97081. doi: 10.1371/journal. pone. 0097081

29. Franson MAH, editor. Standard Methods for the Examination of Water and Wastewater. $15^{\text {th }}$ ed. Washington (DC): American Public Health Association; 1980.

30. Dogan D, Can C, Kocyigit A, Dikilitas M, Taksin A, Bilinc H. Dimethoate-induced oxidative stress and DNA damage in Oncorhynchus mykiss. Chemosphere 2011;84:39-46. doi: 10.1016/j.chemosphere.2011.02.087

31. Dar SZ, Yousuf AR, Balkhi MH, Ganai FA, Bhat FA. Assessment of endosulfan induced genotoxicity and mutagenicity manifested by oxidative stress pathways in freshwater cyprinid fish crucian carp (Carassius carassius $\mathrm{L}$ ). Chemosphere 2015;120:273-83. doi: 10.1016/j. chemosphere.2014.07.031

32. Sobjak TM, Romao S, Nascimento CZ, Santos AFP, Vogel L, Guimaraes ATB. Assessment of the oxidative and neurotoxic effects of glyphosate pesticide on the larvae of Rhamdia quelen fish. Chemosphere 2017;182:267-75. doi: 10.1016/j. chemosphere.2017.05.031

33. Chandran NN, Fojtova D, Blahova L, Rozmankova E, Blaha L. Acute and (sub)chronic toxicity of the neonicotinoid imidacloprid on Chironomus riparius. Chemosphere 2018;209:568-77. doi: 10.1016/j.chemosphere.2018.06.102

34. Woottong RJ, Evans W, Mills L. Annual cycle in female Threespined sticklebacks (Gasterosteus aculeatus L.) from an upland and lowland population. J Fish Biol 1978;12:331-43. doi: 10.1111/j.1095-8649.1978.tb04178.x

35. McCord JM, Fridovich I. Superoxide dismutase: an enzymatic function for erythrocuprein (hemocuprein). J Biol Chem 1969;244:6049-55. doi: 10.1016/S0021-9258(18)63504-5

36. Beutler E. Red Cell Metabolism: A manual of biochemical methods. $2^{\text {nd }}$ ed. New York: Grune \& Starton; 1975.

37. Ellman GL, Courtney KD, Andres V, Featherstone RM. A new and rapid colorimetric determination of acetylcholinesterase activity. Biochem Pharmacol 1961;7:88-95. doi: 10.1016/00062952(61)90145-9

38. Lowry OH, Rosenbrough NJ, Farr AL, Randall RJ. Protein measurement with folin phenol reagent. J Biol Chem 1951;193:265-75. doi: 10.1016/S0021-9258(19)52451-6

39. Roy NM, Ochs J, Zambrzycka E, Anderson A. Glyphosate induces cardiovascular toxicity in Danio rerio. Environ Toxicol Pharmacol 2016;46:292-300. doi: 10.1016/j.etap.2016.08.010 
40. Sarmah S, Marrs JA. Zebrafish as a vertebrate model system to evaluate effects of environmental toxicants on cardiac development and function. Int J Mol Sci 2016;17:2123. doi: 10.3390/ijms 17122123

41. Incardona JP, Carls MG, Holland L, Linbo TL, Baldwin DH, Myers MS, Peck KA, Tagal M, Rice SD, Scholz NL. Very low embryonic crude oil exposures cause lasting cardiac defects in salmon and herring. Sci Rep 2015;5:13499. doi: 10.1038/ srep13499

42. Main AR, Headley JV, Peru KM, Michel NL, Cessna AJ, Morrissey CA. Widespread use and frequent detection of neonicotinoid insecticides in wetlands of Canada's Prairie Pothole Region. PLoS One 2014;9(3):e92821. doi: 10.1371/ journal.pone.0092821

43. Sanden M, Olsvika PA, Søfteland L, Rasinger JD, Rosenlund G, Garlitoc B, Ibáñez M, Berntssen MHG. Dietary pesticide chlorpyrifos-methyl affects arachidonic acid metabolism including phospholipid remodeling in Atlantic salmon (Salmo salar L.). Aquac 2018;484:1-12. doi: 10.1016/j. aquaculture.2017.10.033

44. Hart LJ, Smith SA, Robertson J, Holladay SD. Exposure of tilapian fish to the pesticide lindane results in hypocellularity of the primary hematopoetic organ (pronephros) and the spleen without altering activity of phagocytic cells in these organs. Toxicology 1997;118:211-21. doi: 10.1016/S0300483X(97)03619-6

45. Wendelaar Bonga SE. The stress response in fish. Physiol Rev 1997;77:591-625. doi: 10.1152/physrev.1997.77.3.591

46. Begum G, Vijayaraghavan S. Alterations in protein metabolism of muscle tissue in the fish Clarias batrachus (Linn) by commercial grade dimethoate. Bull Environ Contam Toxicol 1996;57:223-8. doi: 10.1007/s001289900179

47. Samanta P, Pal S, Mukherjee AK, Ghosh AR. Biochemical effects of glyphosate based herbicide, Excel Mera 71 on enzyme activities of acetylcholinesterase (AChE), lipid peroxidation (LPO), catalase (CAT), glutathione-S-transferase (GST) and protein content on teleostean fishes. Ecotoxicol Environ Saf 2014;104:120-5. doi: 10.1016/j. ecoenv.2014.05.025

48. Binukumari S, Devi KA, Vasanthi J. Applications in environmental risk assessment of biochemical analysis on the Indian fresh water fish, Labeo rohita exposed to monocrotophos pesticides. Environ Toxicol Pharmacol 2016;47:200-5. doi: 10.1016/j.etap.2016.08.014

49. Győri J, Farkas A, Stolyar O, Székács A, Mörtl M, Vehovszky A. Inhibitory effects of four neonicotinoid active ingredients on acetylcholine esterase activity. Acta Biol Hung 2017;68:345 57. doi: 10.1556/018.68.2017.4.1

50. Piner Benli P, Çelik M. In vivo effects of neonicotinoidsulfoximine insecticide sulfoxaflor on acetylcholinesterase activity in the tissues of zebrafish (Danio rerio). Toxics 2021;9:73. doi: 10.3390/toxics9040073

51. Vieira CED, Pérez MR, Acayaba RD, Raimundo CCM, Dos Reis Martinez CB. DNA damage and oxidative stress induced by imidacloprid exposure in different tissues of the neotropical fish Prochilodus lineatus. Chemosphere 2018;195:125-34. doi: 10.1016/j.chemosphere.2017.12.077
52. Tian X, Yang W, Wang D, Zhao Y, Yao R, Ma L, Ge C, Li X, Huang Z, He L, Jiao W, Lin A. Chronic brain toxicity response of juvenile Chinese rare minnows (Gobiocypris rarus) to the neonicotinoid insecticides imidacloprid and nitenpyram. Chemosphere 2018;10:1006-12. doi: 10.1016/j. chemosphere.2018.06.083

53. Topal A, Alak G, Ozkaraca M, Yeltekin AC, Comaklı S, Acıl G, Kokturk M, Atamanalp M. Neurotoxic responses in brain tissues of rainbow trout exposed to imidacloprid pesticide: Assessment of 8-hydroxy-2-deoxyguanosine activity, oxidative stress and acetylcholinesterase activity. Chemosphere 2017;175:186-91. doi: 10.1016/j.chemosphere.2017.02.047

54. Lushchak VI, Bagnyukova TV, Husak VV, Luzhna LI, Lushchak OV, Storey KB. Hyperoxia results in transient oxidative stress and an adaptive response by antioxidant enzymes in goldfish tissues. Int J Biochem Cell Biol 2005;37:1670-80. doi: 10.1016/j.biocel.2005.02.024

55. Ge W, Yan S, Wang J, Zhu L, Chen A, Wang J. Oxidative stress and DNA damage induced by imidacloprid in zebrafish (Danio rerio). J Agric Food Chem 2015;63:1856-62. doi: 10.1021/ jf504895h

56. Velisek J, Stara A. Thiacloprid on early life stages of common carp (Cyprinus carpio). Chemosphere 2018;194:481-7. doi: 10.1016/j.chemosphere.2017.11.176

57. Yan SH, Wang JH, Zhu LS, Chen AM, Wang J. Thiamethoxam induces oxidative stress and antioxidant response in zebrafish (Danio rerio) livers. Environ Toxicol 2016;31:2006-15. doi: 10.1002/tox.22201

58. Shukla S, Jhamtani RC, Dahiya MS, Agarwal R. Oxidative injury caused by individual and combined exposure of neonicotinoid, organophosphate and herbicide in zebrafish. Toxicol Rep 2017;4:240-4. doi: 10.1016/j.toxrep.2017.05.002

59. Dalle-Donne I, Rossi R, Giustarini D, Milzani A, Colombo, R. Protein carbonyl groups as biomarkers of oxidative stress. Clin Chim Acta 2003;329:23-38. doi: 10.1016/S00098981(03)00003-2

60. Sinhorin VD, Sinhorin AP, Teixeira JM, Miléski KM, Hansen PC, Moreira PS, Kawashita NH, Baviera AM, Loro VL. Effects of the acute exposition to glyphosate-based herbicide on oxidative stress parameters and antioxidant responses in a hybrid Amazon fish surubim (Pseudoplatystoma $s p$ ). Ecotoxicol Environ Saf 2014;106:181-7. doi: 10.1016/j. ecoenv.2014.04.040

61. de Moura FR, Brentegani KR, Gemelli A, Sinhorin AP, Sinhorin VDG. Oxidative stress in the hybrid fish jundiara (Leiarius marmoratus $\times$ Pseudoplatystoma reticulatum) exposed to Roundup Original ${ }^{\circledR}$. Chemosphere 2017;185:44551. doi: 10.1016/j.chemosphere.2017.07.030

62. Tabassum H, Dawood AQ, Sharma P, Khan J, Raisuddin S, Parvez S. Multi-organ toxicological impact of fungicide propiconazole on biochemical and histological profile of freshwater fish Channa punctata Bloch. Ecol Indic 2016;63:359-65. doi: 10.1016/j.ecolind.2015.11.052

63. Iturburu FG, Bertrand L, Mendieta JR, Améb MV, Menone ML. An integrated biomarker response study explains more than the sum of the parts: Oxidative stress in the fish Australoheros facetus exposed to imidacloprid. Ecol Indic 2018;93:351-7. doi: 10.1016/j.ecolind.2018.05.019 


\section{Prooksidacijski potencijal klotianidina u kalifornijske pastrve}

Klotianidin je sistemski neonikotidni insekticid koji utječe na središnji živčani sustav kao agonist nikotinskoga receptora za acetilkolin. Iako su ranija istraživanja pokazala njegovu nisku toksičnost u riba, njegova dokazana toksičnost u vodenih beskralježnjaka i nedostatak istraživanja o njegovu djelovanju u mladih riba potaknuli su nas da istražimo njegove štetne učinke na tkivo srca i slezene 10-mjesečnih kalifornijskih pastrva (Oncorhynchus mykiss), izloženih okolišnim koncentracijama od 3, 15 i $30 \mu \mathrm{g} / \mathrm{L}$ u trajanju od 7, 14 i 21 dan. Vidljiv je bio porast razina proteinskih karbonila $\mathrm{i}$ malondialdehida (MDA), koji je potaknuo pojačanu antioksidacijsku aktivnost superoksid dismutaze (SOD), katalaze (CAT) i glutation peroksidaze (GPx) te doveo do povećanja razina glutationa (GSH) u tkivima. Pritom je inhibirao aktivnost acetilkolinesteraze (AChE) i smanjio razine proteina. Masa srčanoga tkiva se povećala, a ona slezene značajno se smanjila. Učinci su bili ovisni o koncentraciji i trajanju izloženosti. Posebice zabrinjava inhibicija AChE u pastrva, premda se smatra da klotianidin cilja isključivo nikotinske receptore za acetilkolin u insekata. Povećana antioksidacijska aktivnost kao odgovor na oksidacijski stres bila je nedostatna da MDA i proteinske karbonile zadrži na normalnim razinama, što upućuje na snažno prooksidacijsko djelovanje ovog insekticida. Zbog toga je potrebno podrobnije istražiti njegove moguće štetne učinke na biološke putove u različitih ribljih vrsta.

KLJUČNE RIJEČI: AChE; CAT; GPx; GSH; MDA; neonikotinoidi; Oncorhynchus mykiss; oksidacijski stres; riba; slezena; SOD; srce 